\title{
Fabrication of a self-assembled honeycomb nanofibrous scaffold to guide endothelial morphogenesis
}

Citation for published version (APA):

Yao, T., Wieringa, P. A., Chen, H., Amit, C., Samal, P., Giselbrecht, S., Baker, M. B., \& Moroni, L. (2020). Fabrication of a self-assembled honeycomb nanofibrous scaffold to guide endothelial morphogenesis. Biofabrication, 12(4), [045001]. https://doi.org/10.1088/1758-5090/ab9988

Document status and date:

Published: 01/10/2020

DOI:

10.1088/1758-5090/ab9988

Document Version:

Publisher's PDF, also known as Version of record

Document license:

Taverne

Please check the document version of this publication:

- A submitted manuscript is the version of the article upon submission and before peer-review. There can be important differences between the submitted version and the official published version of record.

People interested in the research are advised to contact the author for the final version of the publication, or visit the DOI to the publisher's website.

- The final author version and the galley proof are versions of the publication after peer review.

- The final published version features the final layout of the paper including the volume, issue and page numbers.

Link to publication

\footnotetext{
General rights rights.

- You may freely distribute the URL identifying the publication in the public portal. please follow below link for the End User Agreement:

www.umlib.nl/taverne-license

Take down policy

If you believe that this document breaches copyright please contact us at:

repository@maastrichtuniversity.nl

providing details and we will investigate your claim.
}

Copyright and moral rights for the publications made accessible in the public portal are retained by the authors and/or other copyright owners and it is a condition of accessing publications that users recognise and abide by the legal requirements associated with these

- Users may download and print one copy of any publication from the public portal for the purpose of private study or research.

- You may not further distribute the material or use it for any profit-making activity or commercial gain

If the publication is distributed under the terms of Article $25 \mathrm{fa}$ of the Dutch Copyright Act, indicated by the "Taverne" license above, 


\section{PAPER}

\section{Fabrication of a self-assembled honeycomb nanofibrous scaffold to guide endothelial morphogenesis}

To cite this article: Tianyu Yao et al 2020 Biofabrication 12045001

View the article online for updates and enhancements.

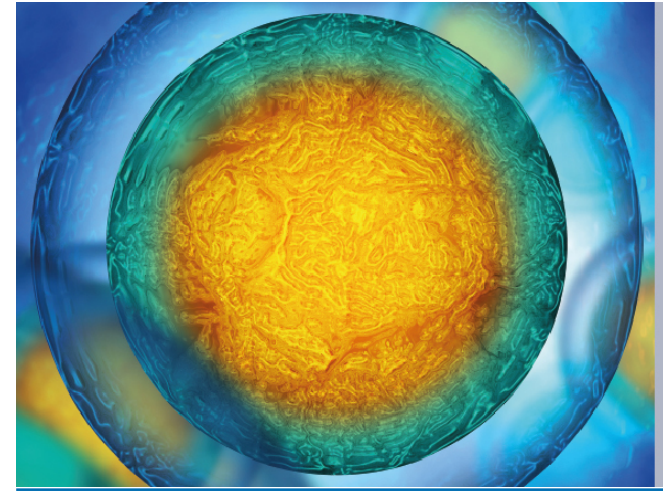

Biophysical Society $\quad$ IOP | ebookS

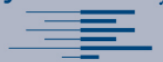

Your publishing choice in all areas of biophysics research.

Start exploring the collection-download the first chapter of every title for free. 


\title{
Biofabrication
}

PAPER

CrossMark

\section{Fabrication of a self-assembled honeycomb nanofibrous scaffold to guide endothelial morphogenesis}

RECEIVED
14 January 2020

PEVISED

12 May 2020

ACCEPTED FOR PUBLICATION

4 June 2020

PUBLISHED

7 July 2020

\author{
Tianyu Yao ${ }^{1}\left(\mathbb{D}\right.$, Paul Andrew Wieringa ${ }^{1}\left(\mathbb{0}\right.$, Honglin $\mathrm{Chen}^{2}$, Chandrakar Amit ${ }^{1}$, Pinak Samal ${ }^{1}$, \\ Stefan Giselbrecht ${ }^{1}$ (D), Matthew B Baker ${ }^{1}$ (D) and Lorenzo Moroni ${ }^{1,3}$ (D) \\ 1 Complex Tissue Regeneration Department, MERLN Institute for Technology Inspired Regenerative Medicine, Maastricht University, \\ Maastricht 6229 ER, The Netherlands \\ 2 Institute for Life Science, School of Medicine, South China University of Technology, Guangzhou 510640, People’s Republic of China \\ E-mail:1.moroni@maastrichtuniversity.nl
}

Keywords: electrospinning, honeycomb, nanofibrous, angiogenesis

Supplementary material for this article is available online

\begin{abstract}
Controlling angiogenesis within tissue engineered constructs remains a critical challenge, especially with regard to the guidance of pre-vascular network formation. Here, we aimed to regulate angiogenesis on a self-assembled honeycomb nanofibrous scaffold. Scaffolds with honeycombs patterns have several desirable properties for tissue engineering, including large surface area, high structural stability and good permeability. Furthermore, the honeycomb pattern resembles early vascular network formation. The self-assembly electrospinning approach to honeycomb scaffolds is a technically simple, rapid, and direct way to realize selective deposition of nanofibers. To evaluate cell compatibility, spreading, proliferation and tube formation, human umbilical vein endothelial cells (HUVECs) were cultured on honeycomb scaffolds, as well as on random scaffolds for comparison. The optimized honeycomb nanofibrous scaffolds were observed to better support cell proliferation and network formation, which can facilitate angiogenesis. Moreover, HUVECs cultured on the honeycomb scaffolds were observed to reorganize their cell bodies into tube-like structures containing a central lumen, while this was not observed on random scaffolds. This work has shown that the angiogenic response can be guided by honeycomb scaffolds, allowing improved early HUVECs organization. The guided organization via honeycomb scaffolds can be utilized for tissue engineering applications that require the formation of microvascular networks.
\end{abstract}

\section{Introduction}

With significant progress in tissue engineering over recent years, there comes a great promise to develop functional constructs resembling the structural organization of native tissues to repair or replace damaged tissues or organs $[1,2]$. Yet, angiogenesis remains one of the most challenging issues $[3,4]$. During formation of new tissue, the vessels created by the natural angiogenic process is required to supply oxygen and nutrition for the regenerating tissues as well as to remove metabolic waste products [5-7]. Lack of efficient vascularization limits the size of tissue-engineered constructs $[1,8]$, and often is the reason for failure of translation. Implantation of tissue constructs in a poorly vascularized site often leads

${ }^{3}$ Author to whom any correspondence should be addressed. to lack of tissue integration and cell death $[9,10]$. As a result, many tissue-engineered constructs also fail in vivo $[1,11,12]$. The angiogenesis process is critical for the successful regeneration of most tissues within the human body $[13,14]$.

Numerous studies have been conducted to improve angiogenesis in tissue engineering $[6,7]$. Recent strategies can be classified into three categories: (1) scaffold design [15-18], (2) growth factor delivery $[19,20]$ and (3) prevascularization [21-23]. Tissue-engineered scaffolds have been considered to be a common and simple strategy to induce angiogenesis [7]. An engineered scaffold should typically provide well-defined biochemical (e.g. surface chemistry [24]) and biophysical cues (e.g. fibrous structure [25], hydrophilicity [26] and stiffness [27]) to mimic the environment of a cell's native extracellular matrix (ECM). Three techniques have proven successful 


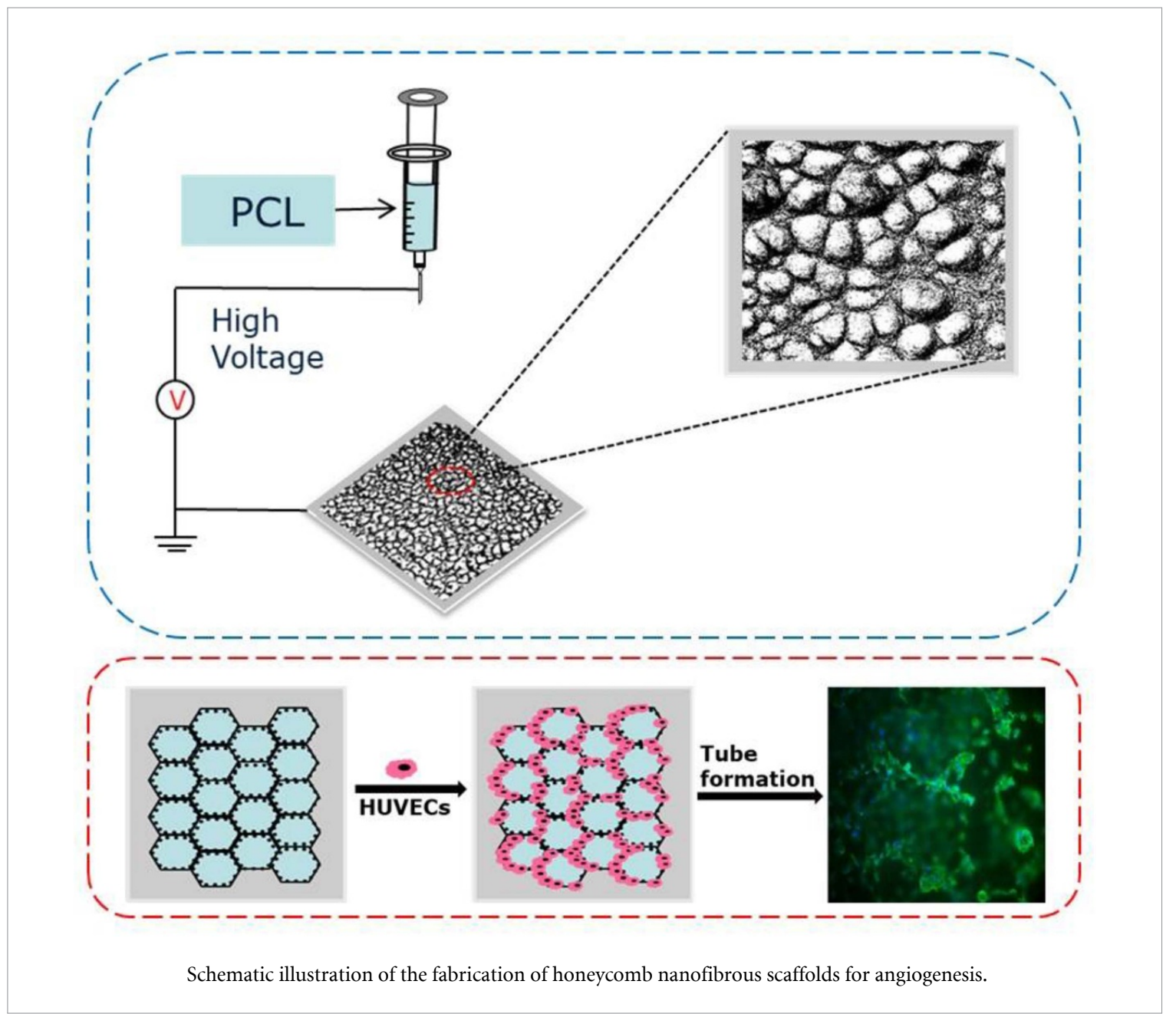

to fabricate the biomimetic nanofibrous structure: molecular self-assembly [28-31], phase separation [32, 33], and electrospinning [34-36]. Electrospinning is a simple and cost-effective processing technique widely used to produce nanofibers for tissue engineering applications [2]. Several fascinating bioinspired nanofibrous structures have been successfully fabricated by electrospinning such as a lotus leaf [37], a silver ragwort leaf [38], a feather [39], a plant tendril [40], a spider web [41], polar bear hair [42], and a honeycomb [43]. The honeycomb-patterned nanofibrous structures have interesting mechanical properties for tissue-engineering, and can be fabricated by the self-assembly method of electrospinning [43-45]. By adjusting the electrospinning parameters, a well-organized honeycomb structure with different diameters of the honeycomb cells can be obtained [43, 45]. Previously, honeycomb-patterned 2D films, fabricated by casting the polymer solution under moist air, was shown to be a suitable substrate to enhance cell adhesion and proliferation [46, 47]. Honeycomb 3D scaffolds have a large surface area, high porosity and favorable mechanical performance, which provide them great potential as porous scaffolds for tissue engineering [48-51].

Blood vessels develop via two consecutive processes, vasculogenesis and angiogenesis [52]. During vasculogenesis, formation of the earliest vessels is achieved. It is reported that fusion of blood-islands leads to the vasculogenesis of honeycomb-shaped primary capillaries [53]. While in angiogenesis, new blood vessels derive from already existing vessels [52]. Angiogenesis involves the proliferation, migration, and remodeling of endothelial cells in the process of tube formation. During angiogenesis, endothelial cells can form honeycomb-like network which facilitate tube formation [54,55]. The presence of a honeycomb-like vascular structure indicates that vasculogenesis and the initial steps of angiogenesis proceeded normally [56]. Therefore, honeycomb network of endothelial cells is a very important morphogenetic trait and can be used to indicate both vasculogenesis and angiogenesis.

Previous studies have shown that endothelial cell morphogenesis into capillary-like structures can be induced and guided by the geometrical distribution of materials $[14,57]$. One study showed that endothelial cells cultured on substrates micropatterned with $10 \mu \mathrm{m}$-wide lines of fibronectin formed capillary tube-like structures containing a central lumen; cells cultured on wider $(30 \mu \mathrm{m})$ lines did not organize into tubes [57]. Moon and colleagues micropatterned PEGDA hydrogels with RGDS in different geometries [14]. As a result, endothelial cells cultured on RGDS 
patterns reorganized their cell bodies into tube-like structures on $50-\mu \mathrm{m}$-wide stripes, but not on wider stripes. These result suggested that endothelial cells morphogenesis can be regulated by geometrical cues. Development of a well-designed scaffold in which capillary tubes consistently form is an important step toward the fabrication of engineered tissues. In this article, we fabricated a nanofibrous scaffold with a unique honeycomb pattern as a biocompatible template to induce the formation of honeycomb-like vascular network. Honeycomb patterns were obtained by the self-assembly of electrospun fibers, and cell culture tests were performed using human umbilical vein endothelial cells (HUVECs). Both monoculture and co-culture with human mesenchymal stromal cells (hMSCs) were used in order to investigate their angiogenetic ability on these scaffolds.

\section{Materials and methods}

\subsection{Fabrication of honeycomb nanofibrous scaffolds}

The electrospinning process used in this study is a homemade electrospinning set-up as mentioned before [58]. Poly(caprolactone) with different molecular weight (PCL; Mn $=\sim 45000$ and $\sim 80000 \mathrm{~g} \mathrm{~mol}^{-1}$ ) were purchased from SigmaAldrich, as also used in our previous studies for fabrication of honeycomb nanofibrous scaffolds [45]. Briefly, PCL was placed in a mixture of chloroform:dimethylformamide (4:1) at a certain concentration (table S1 (available online at stacks.iop.org/BF/12/045001/mmedia)) and then stirred overnight at room temperature before electrospinning to ensure good polymer solubilization. The polymer solution was then filled into a $5 \mathrm{~mL}$ syringe (BD biosciences) and delivered to the stainless steel needle (Unimed S.A.; $0.8 \mathrm{~mm}$ ) via a PFTE tube (Sigma-Aldrich). This steel nozzle was connected with a high voltage supplier to generate the electric field strength during electrospinning. Flow rate of polymer solution was controlled by a syringe pump (Harvard). An aluminum foil collector plate was used to collect fibers under the jet. The distance between the tip of the nozzle and the collecting plate was referred as the working distance (table S1). Honeycomb nanofibrous scaffolds were obtained by a selfassembly electrospinning approach, which was only controlled by the electrospinning parameter. Therefore, no additional equipment was required during electrospinning. Electrospinning parameter for the fabrication of random and honeycomb scaffolds are described in table $\mathrm{S} 1$. The experiments were done at $25^{\circ} \mathrm{C}$ and the humidity was kept around $35 \%$.

\subsection{Characterization of honeycomb structures}

The fiber structure and pattern of honeycomb scaffolds were detected by a scanning electron microscopy (Philips XL30 ESEM). Before observation, the scaffolds were pretreated with gold by using sputter coater 108 Auto set at $30 \mathrm{~mA}$ for $80 \mathrm{~s}$. The honeycomb diameter and size were analyzed with Image J software. The nanofiber alignment into the honeycomb pattern was quantified by an Image J plugin (called Orientation J) to indicate the orientation coherency. The confocal laser scanning microscopy (Keyence) was used to measure the depth of both random and honeycomb electrospun scaffolds.

\subsection{Cell culture and seeding}

HUVECs were provided by Lonza and incubated in endothelial growth medium (EGM, Lonza) which includes endothelial basal medium (EBM) and $\mathrm{EGM}^{\mathrm{TM}}$-2 SingleQuots ${ }^{\mathrm{TM}}$ supplements. For experiments, cells were used between passages 4 and 7 . The tube formation assay was performed as Lonza described in instructions. Briefly, Matrigel ${ }^{\circledR}$ (Corning) was used to coat the wells of 48 -well plates $\left(0.15 \mathrm{ml}\right.$ per well) and was left to incubate at $37{ }^{\circ} \mathrm{C}$ for $30 \mathrm{~min}$. After incubation, HUVECs were seeded on each well at the density of 50000 cells $\mathrm{cm}^{-2}$ in EGM. The tube formation of cells was visualized using a light microscope. As showed in figures 1(e)(f), HUVECs can form the capillary network after $16 \mathrm{~h}$, which was also reported by Lonza. Prior to seeding cells, all PCL electrospun scaffolds were cut into round films (diameter $=15 \mathrm{~mm}$ ), and washed in distilled water to remove the residues from sample preparation, further sterilized by $70 \%$ ethanol solution for $30 \mathrm{~min}$, and dried in a biosafety cabinet. In order to increase cell attachment, the scaffolds were coated using Matrigel ${ }^{\circledR}$ (1:150 dilution in EGM) overnight. HUVECs were seeded on each random and honeycomb electrospun scaffold with a density of 20000 cells $\mathrm{cm}^{-2}$. Then the cells were cultured in EGM for 1,3 , and $5 \mathrm{~d}$ in an incubator at $37^{\circ} \mathrm{C}$.

\subsection{Coculture and cells seeding}

hMSCs (D8011 L, Texas A\&M University) were incubated in basic medium containing $\alpha$-MEM (Gibco) with 10\% FBS (Sigma), $0.2 \mathrm{~mm}$ ascorbic acid (Sigma), $100 \mathrm{U} \mathrm{ml}^{-1}$ penicillin and $100 \mathrm{mg} \mathrm{ml}^{-1}$ streptomycin (Gibco). hMSCs and HUVECs were cocultured at a ratio of $1: 1$ on both scaffolds. The seeding density was kept at 20000 cells $\mathrm{cm}^{-2}$. Cells were then co-cultured in a mixed media composed of EGM and basic medium at 1:1 ratio for $5 \mathrm{~d}$.

\subsection{Live/dead assay}

Cell cytotoxicity was evaluated by a live/dead assay kit (Fisher Scientific) after $1 \mathrm{~d}$ of cells cultured on electrospun scaffolds. Briefly, $1 \mu \mathrm{m}$ of Calcein AM and $6 \mu \mathrm{m}$ of ethidium homodimer-1 (EthD-1) were dissolved in $200 \mu \mathrm{l}$ PBS and then added into cellscaffolds, followed with incubation for $30 \mathrm{~min}$ at $37{ }^{\circ} \mathrm{C}$. Calcein AM was stained by live cells; EthD1 only stained dead cells. After washing with PBS, 

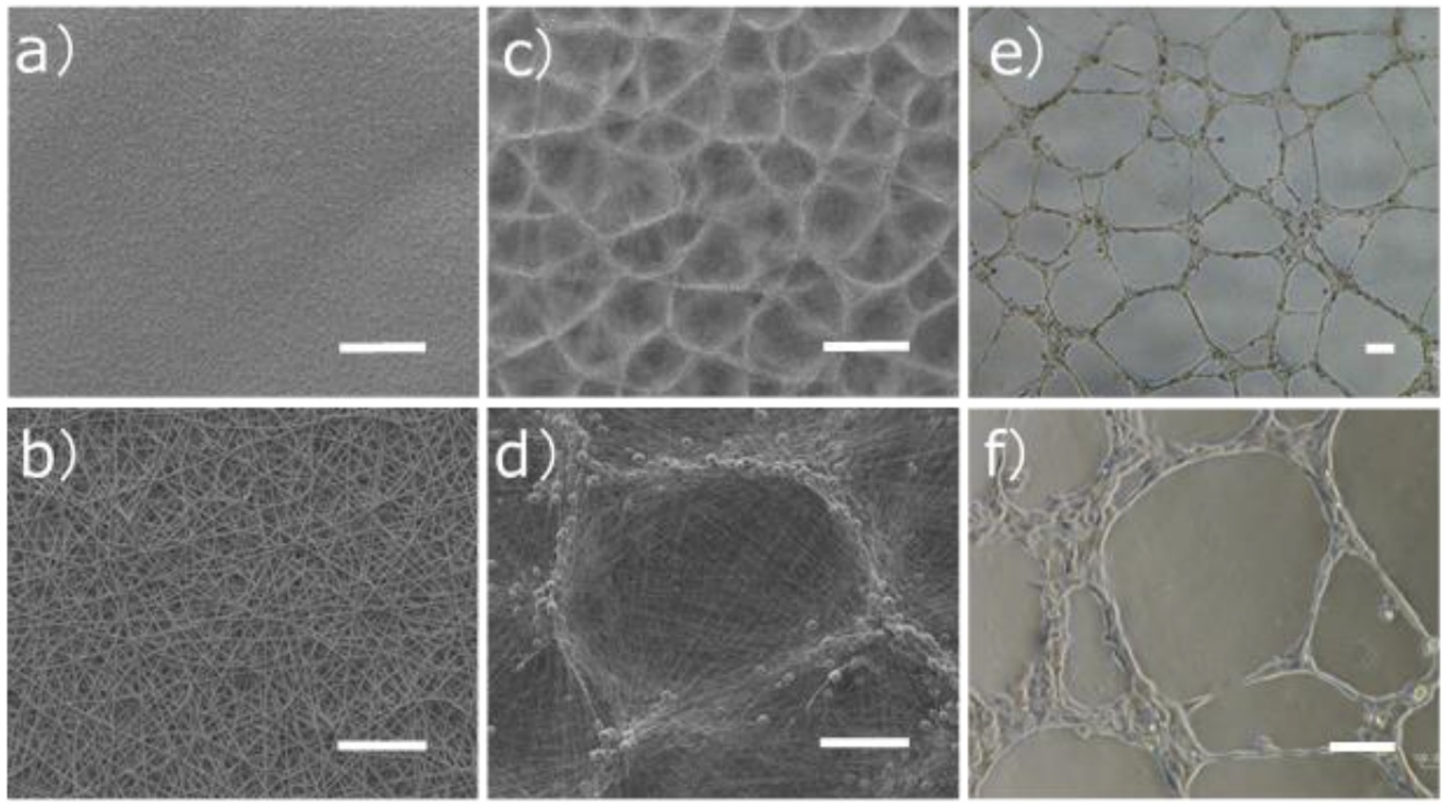

Figure 1. SEM images of random (a) and (b) and honeycomb (c) and (d) PCL electrospun fibers. Images (e) and (f) showed the tube formation of HUVECs cultured on Matrigel-coated wellplate after $16 \mathrm{~h}$. Scale bars are $500 \mu \mathrm{m}$ (a) and (c) and $100 \mu \mathrm{m}(\mathrm{b})$, (d), (e) and (f).

the cells were imaged by using a fluorescence microscopy (Nikon Eclipse Ti-S). Live and dead cells were quantified form live/dead assay images. The percentage of live cells was counted by an equation (Viable cells $\%=$ Live cells/Total cells $\times 100)$.

\subsection{Cell viability and proliferation}

The viability of HUVECs on electrospun scaffolds was determined using the PrestoBlue kit (Thermo Fisher Scientific). Briefly, the cell-scaffolds were immersed in warm PBS and treated with PrestoBlue medium (PrestoBlue: $\mathrm{EGM}=1: 9)$ in an incubator. After $30 \mathrm{~min}$ incubation, $100 \mu \mathrm{l}$ of PrestoBlue medium was added into a black 96 well plate with a clear bottom. The fluorescence of each solution was calculated by using a microplate reader (CLARIO star, BMG Labtech) at $590 \mathrm{~nm}$.

Cell proliferation was assessed after 1, 3, and $5 \mathrm{~d}$ culture by using a CyQUANT ${ }^{\mathrm{TM}}$ Cell Proliferation Assay Kit (Fisher Scientific). The samples were frozen and thawed three times. $250 \mu \mathrm{l}$ of Proteinase $\mathrm{K}$ in Tris/EDTA solution was then added to each sample. After overnight incubation at $56{ }^{\circ} \mathrm{C}$, $40 \mu \mathrm{l}$ of digested samples was placed into a black 96 well plate and the same volume of lysis buffer was added into the well plate for $1 \mathrm{~h}$ incubation. Finally, GR dye $(80 \mu \mathrm{l})$ was transferred into each well and protected in dark for $15 \mathrm{~min}$. Fluorescence of the solution was measured with the plate reader (CLARIO star, BMG Labtech) at emission and excitation wavelengths of 480 and $520 \mathrm{~nm}$, respectively.

\subsection{Immunofluorescence staining}

HUVECs were cultured on the random and honeycomb scaffolds for $5 \mathrm{~d}$ and then fixed using $4 \%$ formaldehyde for $30 \mathrm{~min}$. Fixed samples were washed with PBS for 3 times. After washing, samples were permeabilized with $0.1 \%$ Triton-X 100 in PBS for $15 \mathrm{~min}$ and blocked in blocking buffer (including $0.05 \%$ Tween $20,5 \%$ goat serum, and $1 \%$ BSA in PBS) for $1 \mathrm{~h}$. The cell-scaffolds were soaked in $200 \mu \mathrm{l}$ primary antibodies (anti-CD31 or anti-VECadherin antibody, 1:200 dilution in blocking solution) overnight at $4{ }^{\circ} \mathrm{C}$ after blocking. The incubated samples were immersed in $200 \mu \mathrm{l}$ wash buffer (blocking buffer without goat serum), then placed in secondary antibody solution (goat-anti mouse; Alexa Fluor 488; 1:200 dilution in wash buffer). After $1 \mathrm{~h}$ of incubation with secondary antibody, the samples were cleaned by PBS three times. Cell nuclei were labeled with DAPI for $5 \mathrm{~min}$, followed by washing with PBS. Finally cells on scaffolds were observed with a fluorescent microscope (Nikon Eclipse Ti-S). To quantify angiogenesis, Image J was used to analyze the length of tube formation. A confocal laser excitation microscope (TCS SP8 STED, Leica) was used to access images of HUVECs on scaffolds in different $\mathrm{Z}$-stages. Image of the single tube was consisted of 71 individual $z$-axis stacks. Z-stack images were generated by scanning every $0.15 \mu \mathrm{m}$ in thickness. Huygens software (Scientific Volume Imaging, Hilversum, $\mathrm{NL}$ ) was employed for three-dimensional (3D) reconstruction of confocal images and for analysis of the hollow lumen of HUVECs on honeycomb scaffolds. 
a)

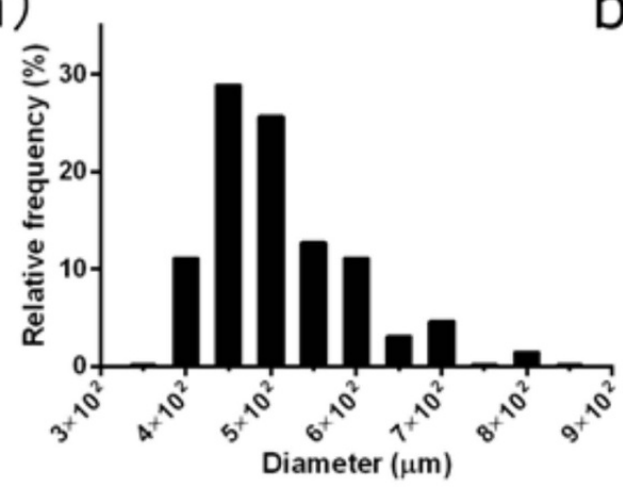

b)

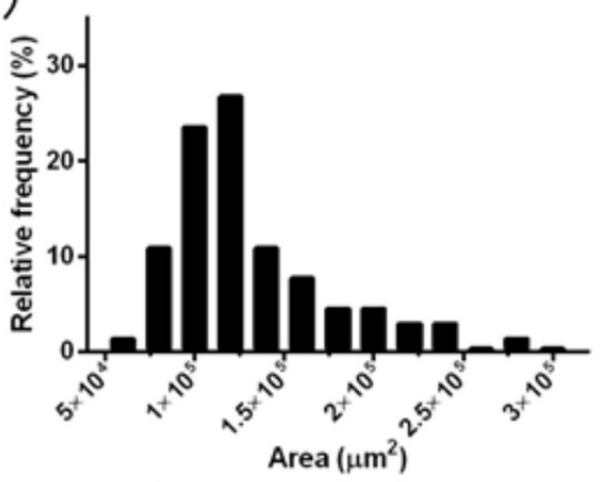

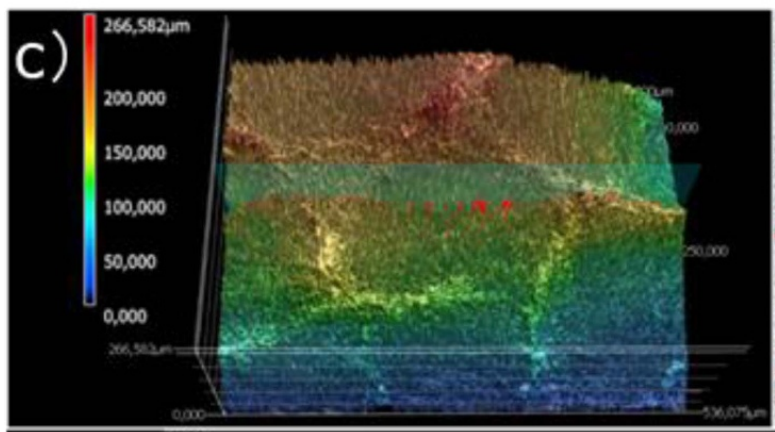
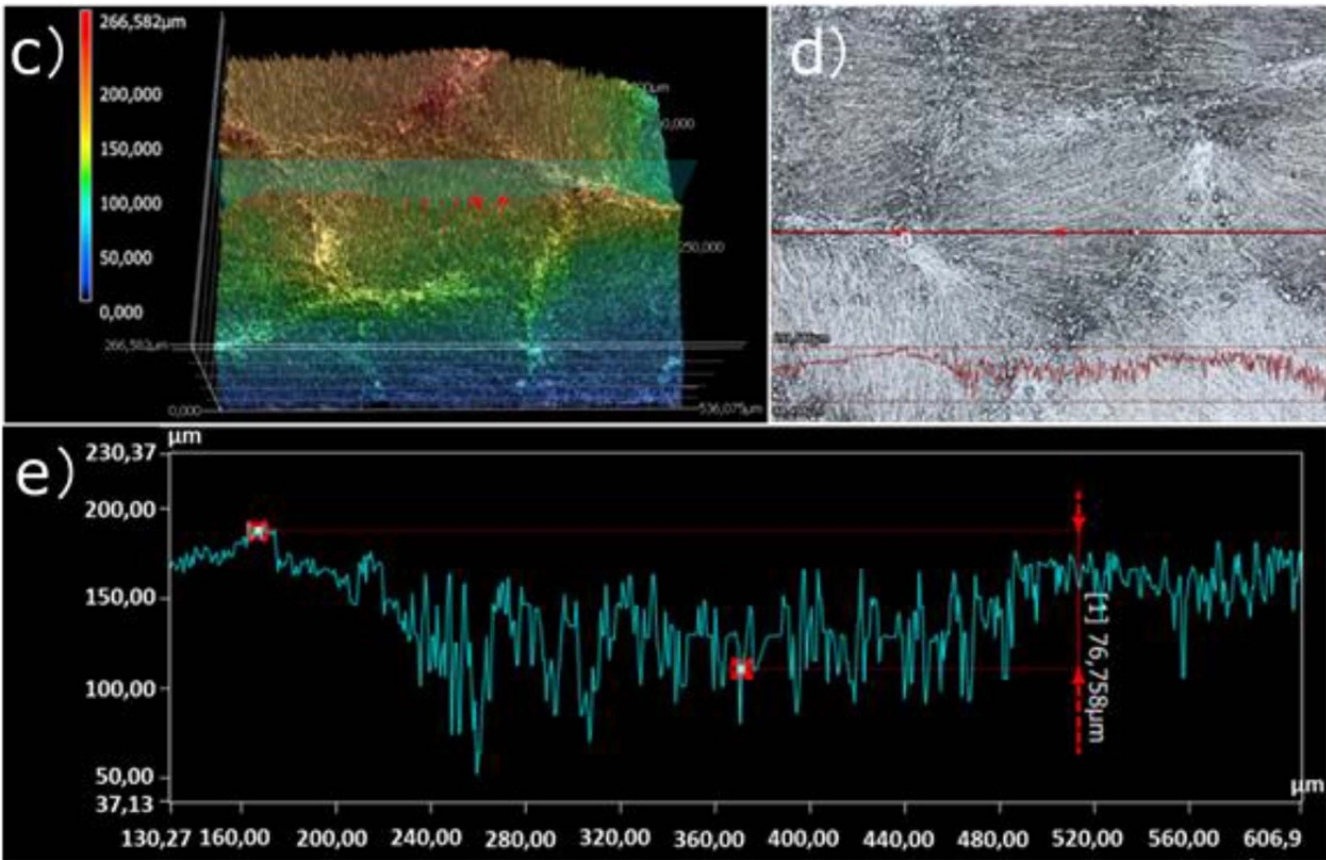

Figure 2. The diameter (a) and area (b) distribution of honeycomb patterns in nanofibrous scaffolds. Images (c) and (d) are optical profilometer scans of a honeycomb pattern. (e) Profile graph measuring the height of honeycomb structure in the nanofibrous scaffolds.

\subsection{Cell morphology and attachment}

SEM images of HUVECs seeded on honeycomb electrospun scaffolds after $5 \mathrm{~d}$ was performed. In brief, samples were cleaned with PBS three times after fixation with $4 \%$ formaldehyde. The fixed samples were dehydrated by a standard ethanol series $(30 \%, 50 \%$, $70 \%, 80 \%, 90 \%, 96 \%$ and $100 \%$ ) for at least $15 \mathrm{~min}$. The dehydrated samples were immersed in hexamethyldisilazane (HMDS; Sigma-Aldrich) for $15 \mathrm{~min}$ twice and then dried overnight. After coating with gold, samples were observed by SEM. Cell morphology and organization on the fibrous scaffolds were also evaluated by using phalloidin (Invitrogen) to label F-actin filaments. After fixation, the cellsscaffolds were incubated in DAPI (Invitrogen, 1:200 in PBS) and Alexa Fluor 568 phalloidin (1:200 in PBS) solution separately according to manufacturer's instructions. Cell were immersed in PBS three times in order to wash extra fluorescence and finally imaged using the fluorescence microscopy and a confocal laser excitation microscope (TCS SP8 STED, Leica).

\subsection{Statistical analysis}

Statistical differences were assessed by using GraphPad Prism 7 software. Unpaired t-test was used to compare the significance between two groups. In all cases, different significance were shown as ${ }^{*} \mathrm{p}<0.05$, ${ }^{* *} \mathrm{p}<0.01$ and ${ }^{* * *} \mathrm{p}<0.001$.

\section{Results and discussion}

Only a few studies have shown the effect of geometrical control on morphogenesis of ECs into tubular structures by using micropatterned stripes substrates $[14,57]$. In the present study, we analyzed the effect of honeycomb patterns on angiogenesis using a self-assembled honeycomb scaffolds. To provide 


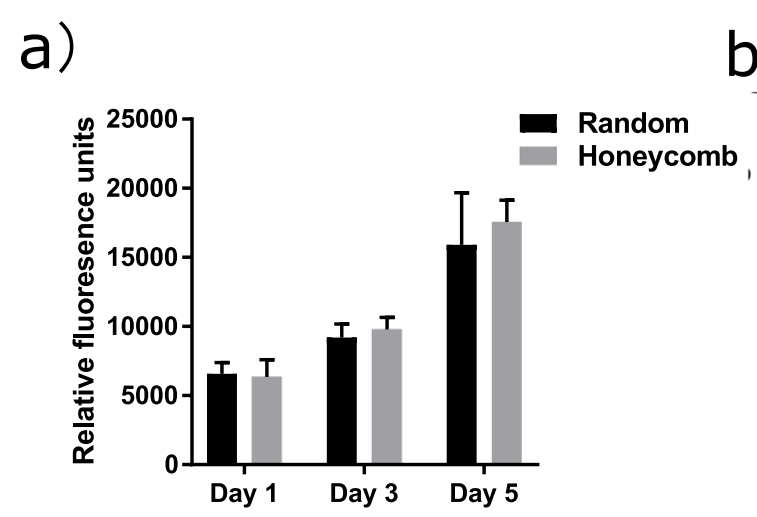

b)

Figure 3. The viability (a) and proliferation (b) of HUVECs cultured for $5 \mathrm{~d}$ on PCL random and honeycomb fibrous scaffolds $(* * \mathrm{p}<0.01)$

structural guidance for cell response, PCL nanofibrous scaffolds with random and honeycomb morphologies were fabricated.

\subsection{Morphology of random and honeycomb electrospun scaffolds}

The morphologies of random and honeycomb electrospun scaffolds were examined by scanning electron microscopy (SEM). SEM images clearly showed a difference in morphology between two types of scaffolds. As shown in figures 1(a)-(b), PCL random fibrous scaffolds were formed with randomly oriented and uniform fibers. The diameter of PCL random fibers was $1.84 \pm 0.14 \mu \mathrm{m}$. From figures 1 (c)(d), the self-assembly of nanofibers into a honeycomb pattern was observed in the scaffolds. The honeycomb pattern was well-organized and distributed uniformly in the electrospun scaffolds, which mimics the tube formation of HUVECs (figure 1(e)-(f)). The average diameter and area of honeycombs were $511 \pm 94 \mu \mathrm{m}$ and $1.33 \pm 0.46 \times 10^{5} \mu \mathrm{m}^{2}$, respectively (see the distribution of diameter and area of honeycomb patterns in figures $2(\mathrm{a})$ and (b)). Due to the competitive actions of surface tension and electrostatic repulsion, the charged nanofibers could self-assemble into the honeycomb structures, which might explain how the patterns were formed [43, 45]. The wall of honeycomb scaffolds were observed by SEM images with higher magnification (figure S1). Most of the fibers were aligned along the wall of the honeycombs, whereas only few fibers were stretched and suspended in the center of the honeycombs. Moreover, the junctions of the honeycomb patterns tend to form three-branchse with an angle approaching $120^{\circ}$ (figures S1(a)-(b)), which is consistent with other electrospun honeycomb studies $[43,44]$. Figures S1(c)-(d) clearly showed the beads structure on the wall and the alignment of nanofibers produced by self-organization of the honeycombs. The level of alignment was measured by the coherency coefficients (figure S1(e)). The coherency coefficient ranges from 0 to 1 , with a value of coherency close to 1 indicating a strongly coherent orientation and greater alignment [59]. In order to compare the alignments of nanofibers and beads in different positions of the honeycomb scaffolds, we measured three sections in the honeycomb scaffolds: nanofibers on the wall, beads structure on the wall, and nanofibers in the center of the honeycomb scaffolds. Analysis results demonstrated that the coherency of nanofibers near the wall of the honeycomb was significantly higher $(0.81 \pm 0.03$ vs. $0.23 \pm 0.14,0.20 \pm 0.08$ and $0.21 \pm 0.05)$ than that on the beads, center of the honeycomb and the random scaffolds. The fiber randomness at the center of the honeycomb is similar to beads and the random scaffolds. Although the beads structure showed randomly oriented morphology, which could interfere with the coherency measurements of the nanofibers on the wall, the nanofibers next to the beads still showed higher coherency than the central area of the honeycomb and random scaffolds.

The 3D image and depth of the honeycomb structure was obtained by optical profilometry, as shown in figures 2(c)-(e). A complete honeycomb was observed in $3 \mathrm{D}$, which showed a similar pattern as what observed by SEM. It can be seen that the wall of honeycombs has a higher depth compared to the central region. The average depth of honeycomb pattern is approximately $82.7 \pm 26.8 \mu \mathrm{m}$, whereas a lower depth of random scaffolds (less than $2 \mu \mathrm{m}$ ) was observed in figure S2. These results showed that the walls of the honeycomb nanofibrous scaffolds display a significant height, providing a 3D surface for cell growth as compared to random scaffolds.

\subsection{HUVECs on random and honeycomb electrospun scaffolds}

Live/dead assays were carried out on random and honeycomb scaffolds after one day of in vitro cell culture. The results can be seen in figure S3. After one day of culture, cells attached to and survived very well on both scaffolds (green indicates live cells). Only 

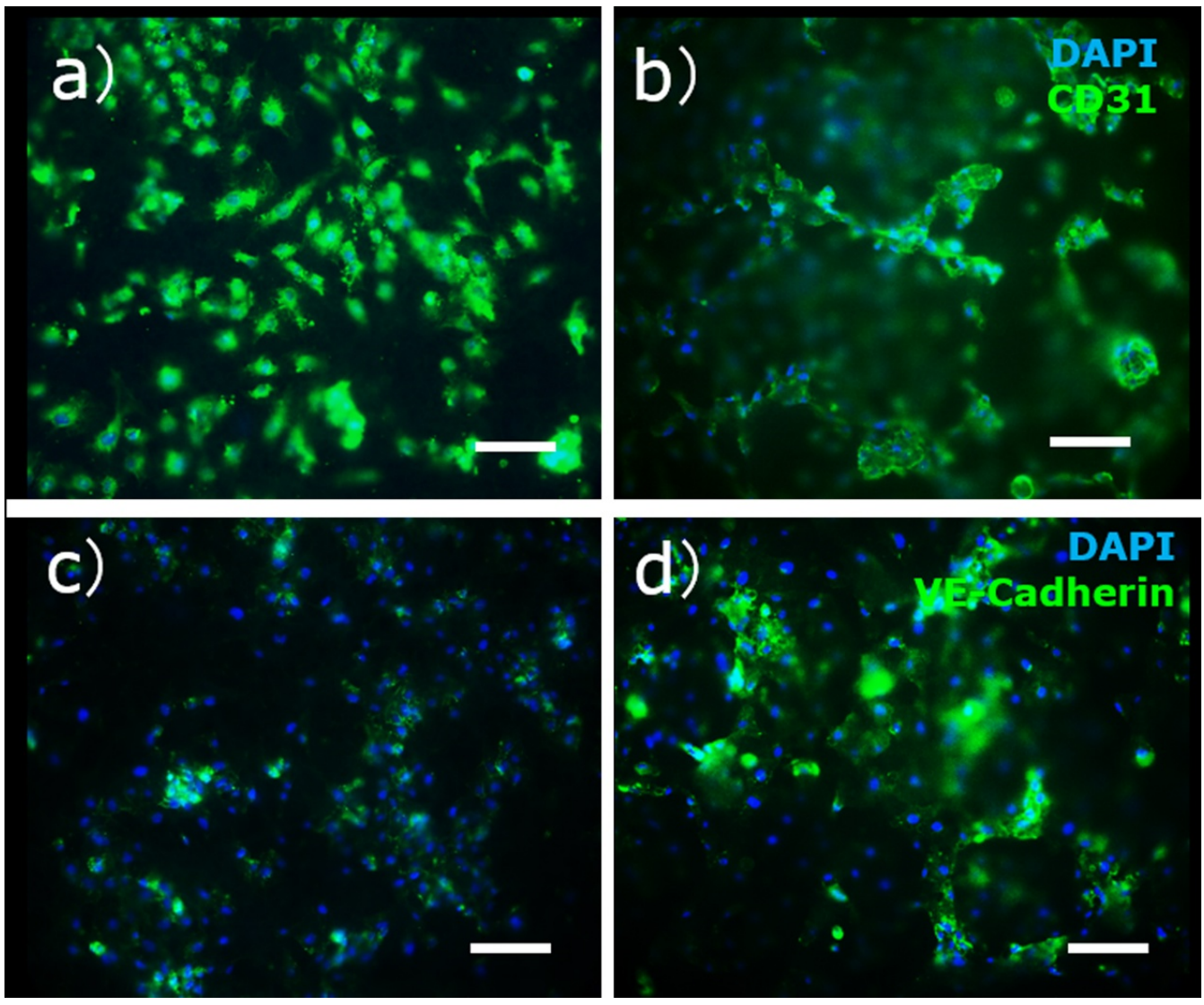

Figure 4. Fluorescence images stained for CD31 (a)-(b), VE-Cadherin(c)-(d) and nuclei (DAPI: blue) of HUVECs on the random (a) and (c) and honeycomb (b) and (d) fibrous scaffolds after $5 \mathrm{~d}$ culture (scale bar: $100 \mu \mathrm{m}$ ).

few dead cells were seen on the scaffolds (red indicates dead cells). The percentage of living cells on random and honeycomb scaffolds were $93 \pm 3 \%$ and $95 \pm 2 \%$, respectively, which indicated good biocompatibility for both scaffolds. Cell viability was evaluated by using the PrestoBlue assay at 1,3 and $5 \mathrm{~d}$ as illustrated in figure 3(a). Results showed that cell viability for both groups gradually increased over $5 \mathrm{~d}$, whereas no significant differences were identified between random and honeycomb scaffolds for the same time point. These observations supported the live/dead findings and confirmed low cytotoxicity of both random and honeycomb nanofibrous scaffolds. In addition, cell proliferation was determined using a CyQUANT ${ }^{\mathrm{TM}}$ Cell Proliferation Assay Kit to measure total DNA content. The samples with HUVECs were harvested after 1, 3 and $5 \mathrm{~d}$ of culture. The DNA content on honeycomb scaffolds was higher than that on random scaffolds at day 5 (figure 3(b)). There was a statistically significant increase of proliferation on honeycomb scaffolds compared to the random ones. Cell proliferation was also evaluated by Ki67 staining, as it is a marker for proliferation. As shown in figure S4, at day 5, the intensity of Ki67 fluorescence-positive cells on the honeycomb scaffolds was much higher than that on the random scaffolds. These results suggested that honeycomb patterns in electrospun scaffolds were capable of positively influencing HUVECs growth, ultimately leading to a higher number of cells compared to the random scaffolds. This might be attributed to the $3 \mathrm{D}$ structure of honeycomb patterns; indeed, the honeycomb scaffolds have higher depth compared to random scaffolds, which offered increased available surface and large porosity for cell growth.

\subsection{Formation and orientation of tube-like} structures

With the purpose of investigating the responses of endothelial cells to honeycomb structures, cells cultured on random and honeycomb patterns were observed by immunocytochemistry staining and SEM. Immunocytochemistry staining with CD31, VE-Cadherin and DAPI was used to evaluate cell identity and morphology on the scaffolds. As shown in figure 4, HUVECs cultured on both scaffolds expressed an endothelial cell phenotype showing positive staining of CD31 and VE-Cadherin. However, the cells responded differently to random and honeycomb nanofibrous scaffolds. Cells on random scaffolds were well spread and showed a disorganized distribution without any tube formation, as shown in CD31 staining (figure 4(a)). Electrospun fibers typically form 2D membranes with small pore size and 

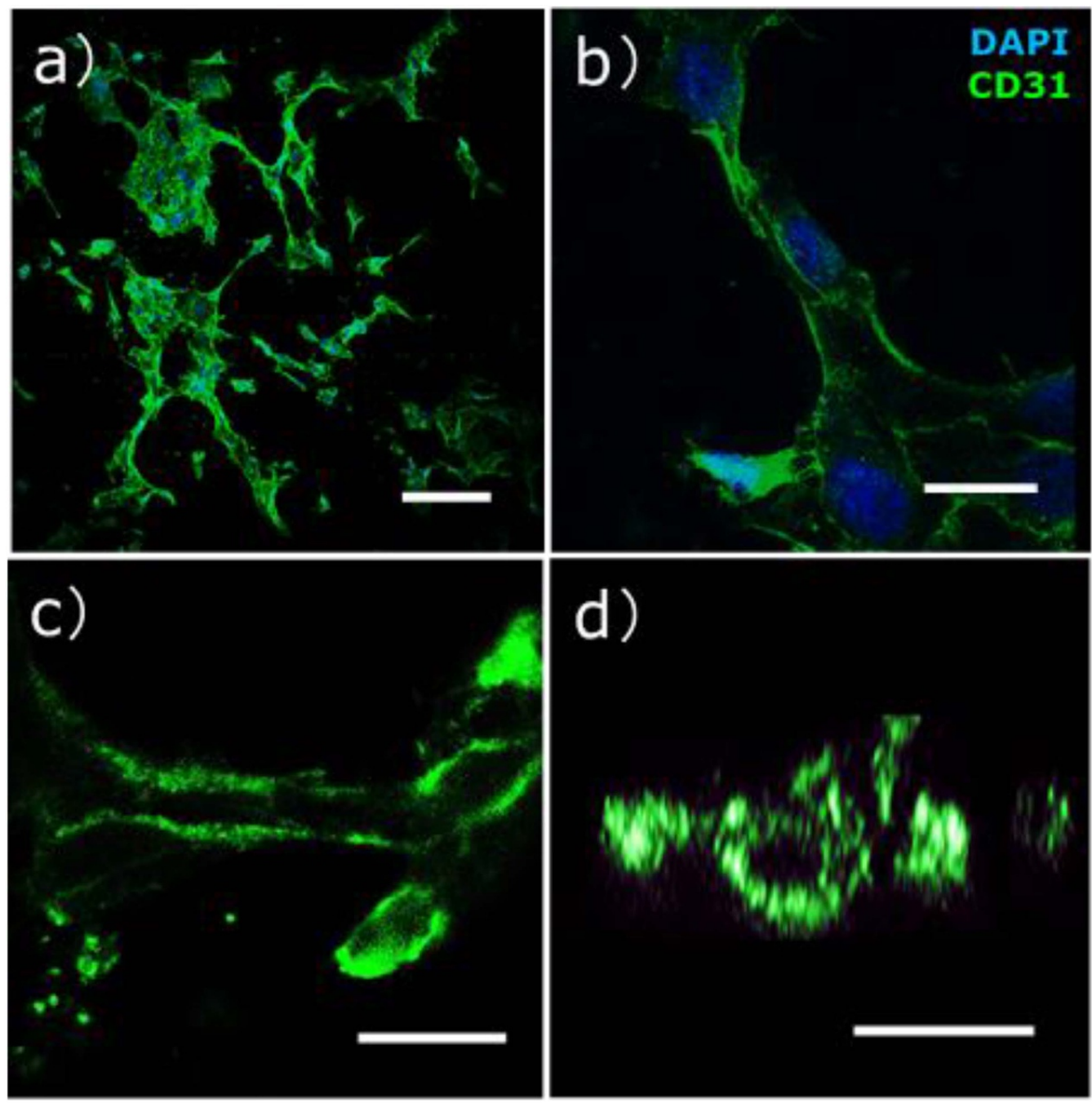

Figure 5. (a)-(b) 3D confocal images of the HUVECs grow on honeycomb scaffolds showing the capability of cells to generate 3D tube-like structures. (c)-(d) The lumen cavity appears as a negatively stained central space when viewed in horizontal (XY) and vertical (YZ) cross section. Nuclei were labeled with DAPI (blue) and HUVECs were stained with an anti-CD31 antibody (green). Scale bars are $100 \mu \mathrm{m}$ (a), $20 \mu \mathrm{m}$ (b), $10 \mu \mathrm{m}$ (c) and $5 \mu \mathrm{m}$ (d).

low thickness [60], which typically do not allow cell infiltration and reorganization.

Many researchers have reported that HUVECs grown on random electrospun fibers display a wellspread polygonal morphology and irregular distribution, which should be guided by the densely packed and randomly oriented nanofibers [61-63]. Sun et al reported that HUVECs on electrospun cross-linked gelatin membranes formed spherical or spindle morphology with plenty of pseudopodia attached to the fibers [62]. In another study, Li et al showed that HUVECs grown on polyurethane (PU) fibers displayed a small spherical or narrow shape and non-spreading morphology [61]. Recent findings explained that changing the mechanical properties (e.g. stiffness) of electrospun fibers could affect cell morphology and the vessel formation capacity of HUVECs [63, 64]. For example, low fiber stiffness of electrospun scaffolds could exhibit sufficiently stretched and expanding cell morphologies, whereas small cell areas and spindle cell morphology were present for HUVECs grown on stiff electrospun scaffolds. Low fiber stiffness also proved the cell capacity to actively recruit nearby fibers, which increased cell adhesion, infiltration and finally promoted cell migration [65]. In our study, PCL random fibers are most likely stiff for cells, which resulted in no observed penetration or migration into the scaffolds (figure 4(a)).

In contrast, cells on the honeycomb scaffolds showed a preferential localization along the walls of the honeycomb pattern, which is mainly due to the alignment of the nanofibers in the honeycomb scaffolds, and were capable of migrating through the scaffolds thickness (figure S6). It has been widely reported that aligned nanofibers could provide contact guidance cues for endothelial cells [66-68]. In addition, the beads structure on the wall could afford a large attaching area for cells to anchor, which might be another reason to explain the preferential location of HUVECs after seeding. Cord-like structures organized by HUVECs were also formed when cells were 

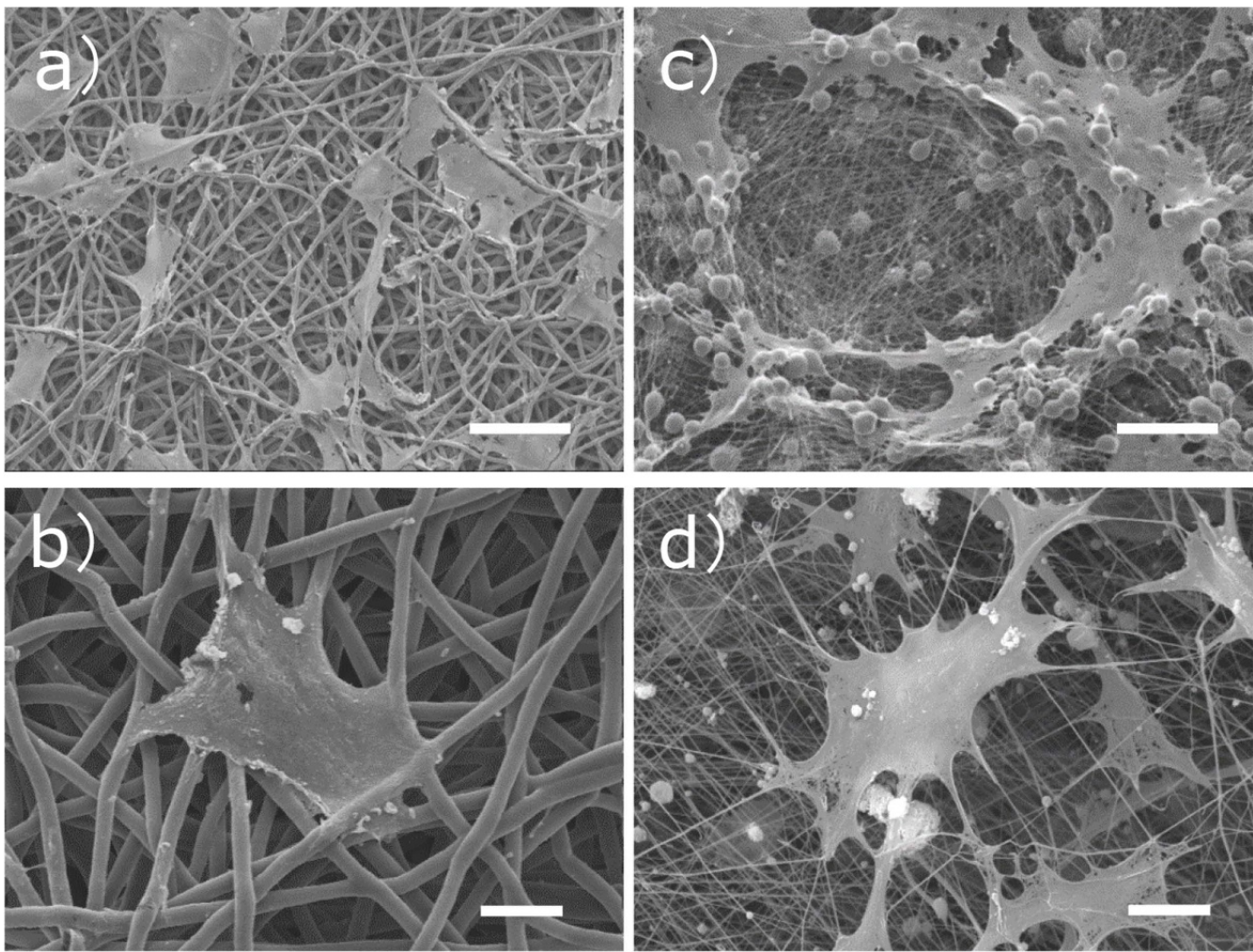

Figure 6. SEM images of HUVECs on random (a) and (b) and honeycomb (c) and (d) PCL fibers after 5 d culture. Scale bars are $50 \mu \mathrm{m}(\mathrm{a})$ and (c) and $10 \mu \mathrm{m}(\mathrm{b})$ and (d).

cultured on honeycomb scaffolds (figure 4(b)). This phenomenon resulted in the formation of $3 \mathrm{D}$ tubelike structures on honeycomb scaffolds, as also confirmed by $3 \mathrm{D}$ confocal images (figure 5). Confocal images of horizontal and vertical (figures $5(\mathrm{c})-(\mathrm{d})$ ) cross sections confirmed the existence of the central lumen, which appeared as a negatively stained central space extending along multiple cell lengths. Figure S5 also illustrated another negatively labeled lumen and the position of this lumen. We quantified about 30 tubes from multiple CD31 staining images on one scaffolds and the length of tubes was $247.6 \pm 152.5 \mu \mathrm{m}$. Cell infiltration was analyzed by slicing along the Z-stack obtained from confocal microscopy, from the bottom to top of the honeycomb scaffolds, allowing us to observe cell penetration into the honeycomb pattern (figure S6). These results clearly demonstrate the successful penetration of HUVECs up to $50 \mu \mathrm{m}$ in the honeycomb scaffolds. HUVECs were also seeded on a 3D printed honeycomb scaffolds in order to supply an additional pattern to assess the specificity of tubular formation. HUVECs grew along the 3D printed scaffolds without showing any clear tubular structure (figure S7). The junction of HUVECs in the scaffolds was further revealed by VE-Cadherin staining (figures 4(c) and (d)). VE-Cadherin is the basic adhesion junction in endothelial cells, which is important for cell to cell contacts [69]. It was interesting to note that more VE-Cadherin (green) was observed when cells were cultured on the honeycomb nanofibrous scaffolds compared to random scaffolds, indicating that cells generated stronger cohesion and organization of cell-cell junctions. Moreover, the honeycomb pattern on electrospun scaffolds could lead to the ability of HUVECs to contact and form a tubelike structure. As proven previously, the formation of cell-cell connections is essential for endothelial cells to maintain cell-cell adhesion and communication, which subsequently directs endothelial cell morphogenesis and guides the early development of vascular networks [70]. The addition of micro-/ nanotextured topographies to materials could effectively activate angiogenic signaling pathways, which are crucial in the process of angiogenesis [71, 72]. A regular pattern such as the honeycomb guarantees that cells in the entire construct are never further away from the next vessel than half of the long diagonal of a honeycomb cell. The results demonstrated in our study therefore supported that the geometries of the honeycomb patterns might also activate angiogenic signaling pathways in HUVECs and stimulate reorganization of cell bodies into tube-like structures.

The morphology of cells grown on both scaffolds was observed by SEM (figure 6). HUVECs cultured on random scaffolds were widely spread and showed polygonal shape without a preferential distribution, whereas those on honeycomb scaffolds grew along the wall of the honeycomb and preferred to retain at 

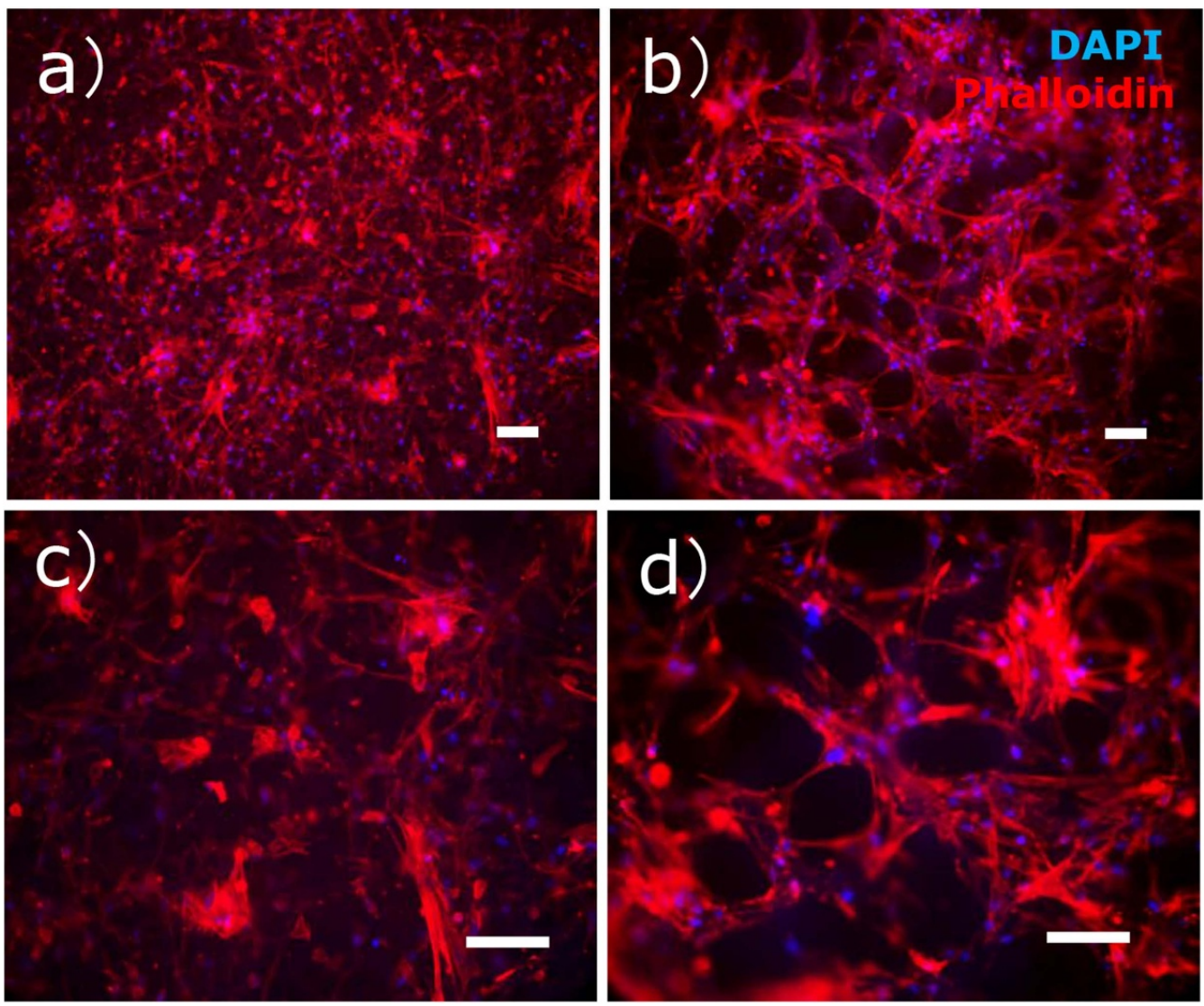

Figure 7. Fluorescence images stained for F-actin (phalloidin: red) and nuclei (DAPI: blue) of hMSCs-HUVECs on random (a) and (c) and honeycomb (b) and (d) PCL electrospun scaffolds after $5 \mathrm{~d}$ of co-culture. Scale bars are $100 \mu \mathrm{m}$.

the wall. This result is consistent with immunostaining. More SEM images of HUVECs on honeycomb scaffolds with low magnification are shown in figure S8. We also looked into single cells grown on scaffolds (figures 6(b) and (d)). We observed that cells on the random scaffolds were more elliptical with less pseudopodia. In contrast, cells on honeycomb scaffolds were more stretched out, and some pseudopodia were elongated along the fiber direction. More pseudopodia of cells on honeycomb could firmly attach to the nanofibers and might help cells migrate in three dimensions. Interestingly, with smaller fiber diameter in honeycomb scaffolds the pseudopodia were longer and smaller on attached fibers. This observation has also been reported by Li et al [73].

\subsection{Co-cultures on honeycomb nanofibrous scaffolds}

While ECs are the cell lines capable of forming blood vessels in human tissue, perivascular cells, especially pericytes, have been shown to have great impact on vascularization. It was previously demonstrated the hMSCs can act as pericytes and stabilize the formed vascular structures when co-cultured with ECs in defined conditions. Therefore, co-culturing hMSCs with endothelial cells can be an effective strategy to form vascularization, and to stabilize blood vessels. To determine the topographical influence of honeycomb scaffolds on co-cultured cell behavior, HUVECs and hMSCs were co-cultured up to $5 \mathrm{~d}$. DAPI (blue)/phalloidin (red) staining was performed to observe overall cell distribution and organization.

As shown in figure 7 , the honeycomb structure in electrospun scaffolds could guide cell distribution. On random scaffolds, cells exhibited wide spreading of cellular actin filaments and were randomly distributed throughout the nanofibers without any preference. While on honeycomb scaffolds, most of cells distributed on the wall of the honeycomb and stretched along the attached nanofibers. It seems that the cells preferred to spread at the top of the honeycomb pattern, growing along the wall. $3 \mathrm{D}$ confocal images also proved this observation (figure S9). The co-culture further corroborated the trend observed in HUVECs monoculture showing that cell behavior can be regulated and guided by honeycomb nanofibrous scaffolds. It was also interesting to note that VE-Cadherin staining was much higher for the HUVECs co-culture with hMSCs on honeycomb scaffolds compared on the random scaffolds, as shown in figure 8 . The results demonstrated that HUVECs/hMSCs co-culture on the honeycomb scaffolds generated strong cohesion and organization of 

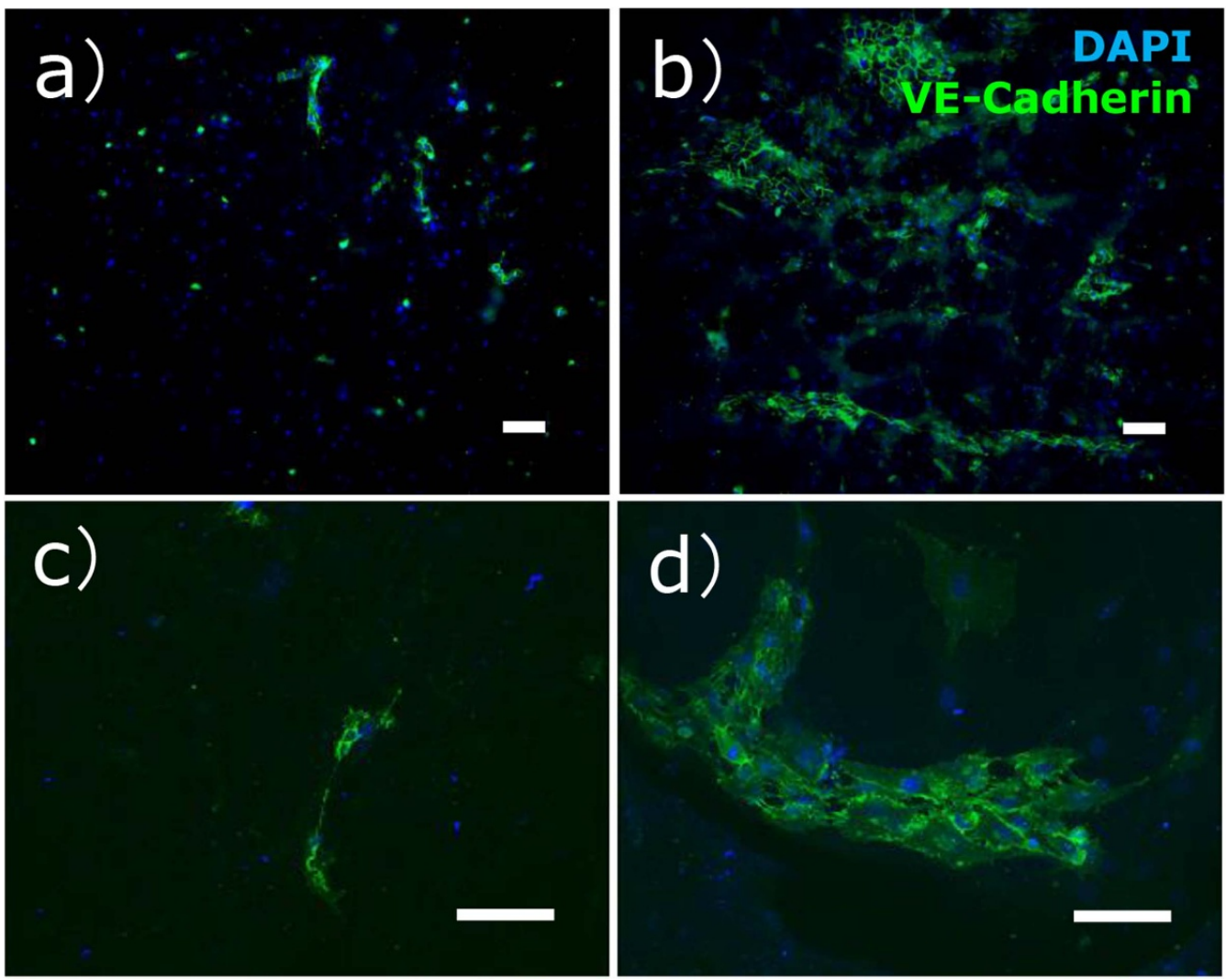

Figure 8. Immunoflourescence staining of VE-Cadherin in HUVECs after co-culture with hMSCs on random (a) and (c) and honeycomb (b) and (d) scaffolds at day 5. Scale bars are $100 \mu \mathrm{m}$.

the inter-cellular junctions. However, it was much less on the random scaffolds. This result obtained in the co-culture investigation also supported that the honeycomb scaffolds could facilitate desirable intracellular connection and the following endothelial cell morphogenesis.

In HUVECs monocultures, immunofluorescent images showed the relative expression of CD31 and VE-Cadherin on different scaffolds (figure 5). VECadherin expression of HUVECs became more pronounced and cells were observed forming tube-like structure on honeycomb scaffolds after $5 \mathrm{~d}$ culture. In hMSCs/HUVECs cocultures, VE-cadherin expression was also relatively higher on honeycomb scaffolds compared to random scaffolds. Especially, cocultures of hMSCs with HUVECs were observed forming obvious network and clear cell-junctions on honeycomb scaffolds compared to HUVECs monoculture (figure S10). hMSCs were located at the surrounding of HUVECs (figure S10(b)), which could be hypothesized to act as pericytes and stabilize the formed vascular structures. The cellular crosstalk between endothelial cells and hMSCs has been well studied [74]. It has been reported that hMSCs can secrete cytokines and angiogenic growth factors, including VEGF [75], Ang-1 [76], IGF-1 [77], and PDGF [78] among others, to influence endothelial cell behavior. In addition, the extracellular matrix produced by hMSCs may support the tube formation of HUVECs and stabilize vessel networks when the cells are co-cultured in direct contact [79, 80]. Our coculture results also proved that hMSCs facilitated vessel network formation of HUVECs on honeycomb scaffolds.

Finally, it is known that different scaffolds' pattern have a different effect on cell behavior. In this study, we only compared honeycomb scaffolds with random scaffolds, but did not investigate the different size of honeycomb nanofibrous scaffolds or other patterns on guiding endothelial cell organization into tubelike formation. Our previous findings proved that honeycomb nanofibrous scaffolds with different size and gradients could be successfully fabricated with the same electrospinning method, by simply changing electrospun parameters. A more in-depth analysis of different honeycomb scaffolds on endothelial cell morphogenesis should be studied in future research, to further understand how much control over the process of angiogenesis can be provided by such geometric cues. Moreover, future studies should also aim at understanding if honeycomb nanofibrous scaffolds could provide geometric cues able to influence the organization of other types of cells. Understanding whether other types of vascular cells could be guided by honeycomb patterns and form tubular network would be important for the fabrication of vascularized tissues, which has great potential applications in tissue regeneration. 


\section{Conclusion}

In this study, we fabricated honeycomb nanofibrous scaffolds by the self-assembly process of electrospinning. The fabricated honeycomb scaffolds can support endothelial cells adhesion, proliferation, and guide cell migration on the scaffolds. Compared with random electrospun scaffolds, the honeycomb scaffolds significantly promoted HUVECs proliferation and influenced the distribution of cells. It is interesting that the honeycomb electrospun scaffolds can regulate HUVECs morphogenesis into capillary-like structures with a central lumen. Moreover, higher VE-Cadherin staining was observed when HUVECs were mono-cultured and co-cultured with hMSCs on the honeycomb nanofibrous scaffolds compared to random scaffolds. This study provides evidence that endothelial cells are highly sensitive to their local microenvironment and can respond to geometric cues to form capillary networks. These results show that the better geometric control of endothelial cells during angiogenesis give honeycomb scaffolds potential for vascular tissue engineering.

\section{Acknowledgments}

T Yao are supported by China Scholarship Council (Grant No. 201508610081). This research project has been made possible thanks to the support of the Dutch Province of Limburg.

\section{ORCID iDs}

Tianyu Yao () https://orcid.org/0000-0003-09195441

Paul Andrew Wieringa (1) https://orcid.org/00000002-3290-5125

Stefan Giselbrecht (1) https://orcid.org/0000-00021354-0167

Matthew B Baker (1) https://orcid.org/0000-00031731-3858

Lorenzo Moroni (i) https://orcid.org/0000-0003$1298-6025$

\section{References}

[1] Chakraborty S, Ponrasu T, Chandel S, Dixit M and Muthuvijayan V 2018 Reduced graphene oxide-loaded nanocomposite scaffolds for enhancing angiogenesis in tissue engineering applications R. Soc. Open Sci. 5172017

[2] Khorshidi S, Solouk A, Mirzadeh H, Mazinani S, Lagaron J M, Sharifi S and Ramakrishna S 2016 A review of key challenges of electrospun scaffolds for tissue engineering applications J. Tissue Eng. Regen. Med. 10 715-38

[3] Guo X, Elliott C G, Li Z, Xu Y, Hamilton D W and Guan J 2012 Creating 3D angiogenic growth factor gradients in fibrous constructs to guide fast angiogenesis Biomacromolecules 13 3262-71

[4] Nillesen S T, Geutjes P J, Wismans R, Schalkwijk J, Daamen W F and van Kuppevelt T H 2007 Increased angiogenesis and blood vessel maturation in acellular collagen-heparin scaffolds containing both FGF2 and VEGF Biomaterials 28 1123-31

[5] Hadjizadeh A, Ghasemkhah F and Ghasemzaie N 2017 Polymeric scaffold based gene delivery strategies to improve angiogenesis in tissue engineering: a review Polym. Rev. 57 505-56

[6] Rouwkema J and Khademhosseini A 2016 Vascularization and angiogenesis in tissue engineering: beyond creating static networks Trends Biotechnol. 34 733-45

[7] Rouwkema J, Rivron N C and van Blitterswijk C A 2008 Vascularization in tissue engineering Trends Biotechnol. 26 434-41

[8] Lovett M, Lee K, Edwards A and Kaplan D L 2009 Vascularization strategies for tissue engineering Tissue Eng. B 15 353-70

[9] Griffith C K, Miller C, Sainson R C, Calvert J W, Jeon N L, Hughes C C and George S C 2005 Diffusion limits of an in vitro thick prevascularized tissue Tissue Eng. 11 257-66

[10] Singh S, Wu B M and Dunn J C 2011 The enhancement of VEGF-mediated angiogenesis by polycaprolactone scaffolds with surface cross-linked heparin Biomaterials 32 2059-69

[11] Bae H, Puranik A S, Gauvin R, Edalat F, Carrillo-Conde B, Peppas N A and Khademhosseini A 2012 Building vascular networks Sci. Transl. Med. 4 160ps23

[12] Hunziker E, Spector M, Libera J, Gertzman A, Woo S L-Y, Ratcliffe A, Lysaght M, Coury A, Kaplan D and Vunjak-Novakovic G 2006 Translation from research to applications Tissue Eng. 12 3341-64

[13] Laschke M W, Harder Y, Amon M, Martin I, Farhadi J, Ring A, Torio-Padron N, Schramm R, Rücker M and Junker D 2006 Angiogenesis in tissue engineering: breathing life into constructed tissue substitutes Tissue Eng. 12 2093-104

[14] Moon J J, Hahn M S, Kim I, Nsiah B A and West J L 2008 Micropatterning of poly (ethylene glycol) diacrylate hydrogels with biomolecules to regulate and guide endothelial morphogenesis Tissue Eng. A 15 579-85

[15] Druecke D, Langer S, Lamme E, Pieper J, Ugarkovic M, Steinau H U and Homann H H 2004 Neovascularization of poly (ether ester) block copolymer scaffolds in vivo: long term investigations using intravital fluorescent microscopy $J$. Biomed. Mater. Res. A 68 10-18

[16] Hutmacher D W 2001 Scaffold design and fabrication technologies for engineering tissues - state of the art and future perspectives J. Biomater. Sci. Polym. Ed. 12 107-24

[17] Karageorgiou V and Kaplan D 2005 Porosity of 3D biomaterial scaffolds and osteogenesis Biomaterials 26 5474-91

[18] Yang S, Leong K-F, Du Z and Chua C-K 2001 The design of scaffolds for use in tissue engineering. Part I. Traditional factors Tissue Eng. 7 679-89

[19] Hirschi K K, Skalak T C, Peirce S M and Little C D 2002 Vascular assembly in natural and engineered tissues Ann. N. Y. Acad. Sci. 961 223-42

[20] Richardson T P, Peters M C, Ennett A B and Mooney D J 2001 Polymeric system for dual growth factor delivery Nat. Biotechnol. 191029

[21] Choong C S, Hutmacher D W and Triffitt J T 2006 Co-culture of bone marrow fibroblasts and endothelial cells on modified polycaprolactone substrates for enhanced potentials in bone tissue engineering Tissue Eng. 12 2521-31

[22] Shepherd B R, Enis D R, Wang F, Suarez Y, Pober J S, Schechner J S, Shepherd B R, Enis D R, Wang F and Suarez Y 2006 Vascularization and engraftment of a human skin substitute using circulating progenitor cell-derived endothelial cells Faseb J. 20 1739-41

[23] Unger R E, Sartoris A, Peters K, Motta A, Migliaresi C, Kunkel M, Bulnheim U, Rychly J and Kirkpatrick C J 2007 Tissue-like self-assembly in cocultures of endothelial cells and osteoblasts and the formation of microcapillary-like structures on three-dimensional porous biomaterials Biomaterials 28 3965-76 
[24] Grafahrend D, Heffels K-H, Beer M V, Gasteier P, Möller M, Boehm G, Dalton P D and Groll J 2011 Degradable polyester scaffolds with controlled surface chemistry combining minimal protein adsorption with specific bioactivation Nat. Mater. 1067

[25] Meng Z, Wang Y, Ma C, Zheng W, Li L and Zheng Y 2010 Electrospinning of PLGA/gelatin randomly-oriented and aligned nanofibers as potential scaffold in tissue engineering Mater. Sci. Eng. C 30 1204-10

[26] Diego R B, Olmedilla M P, Aroca Á S, Ribelles J G, Pradas M M, Ferrer G G and Sánchez M S 2005 Acrylic scaffolds with interconnected spherical pores and controlled hydrophilicity for tissue engineering J. Mater. Sci. 40 4881-7

[27] Amoroso N J, D’Amore A, Hong Y, Rivera C P, Sacks M S and Wagner W R 2012 Microstructural manipulation of electrospun scaffolds for specific bending stiffness for heart valve tissue engineering Acta Biomater. 8 4268-77

[28] Hartgerink J D, Beniash E and Stupp S I 2001 Self-assembly and mineralization of peptide-amphiphile nanofibers Science 294 1684-8

[29] Hartgerink J D, Beniash E and Stupp S I 2002 Peptide-amphiphile nanofibers: a versatile scaffold for the preparation of self-assembling materials Proc. Natl Acad. Sci. 99 5133-8

[30] Goor O J, Hendrikse S I, Dankers P Y and Meijer E 2017 From supramolecular polymers to multi-component biomaterials Chem. Soc. Rev. 46 6621-37

[31] Webber M J, Appel E A, Meijer E and Langer R 2016 Supramolecular biomaterials Nat. Mater.15 13-26

[32] Chen V J and Ma P X 2004 Nano-fibrous poly (L-lactic acid) scaffolds with interconnected spherical macropores Biomaterials 25 2065-73

[33] Ma P X and Zhang R 1999 Synthetic nano scale fibrous extracellular matrix J. Biomed. Mater. Res. B 46 60-72

[34] Huang Z-M, Zhang Y-Z, Kotaki M and Ramakrishna S 2003 A review on polymer nanofibers by electrospinning and their applications in nanocomposites Compos. Sci. Technol. 63 2223-53

[35] Li D and Xia Y 2004 Electrospinning of nanofibers: reinventing the wheel? Adv. Mater. 16 1151-70

[36] Reneker D H and Chun I 1996 Nanometre diameter fibres of polymer, produced by electrospinning Nanotechnology 7216

[37] Jiang L, Zhao Y and Zhai J 2004 A lotus leaf like superhydrophobic surface: a porous microsphere/nanofiber composite film prepared by electrohydrodynamics Angew. Chem. 116 4438-41

[38] Miyauchi Y, Ding B and Shiratori S 2006 Fabrication of a silver-ragwort-leaf-like super-hydrophobic micro/nanoporous fibrous mat surface by electrospinning Nanotechnology 175151

[39] Bormashenko E, Bormashenko Y, Stein T, Whyman G and Bormashenko E 2007 Why do pigeon feathers repel water? Hydrophobicity of pennae, Cassie-Baxter wetting hypothesis and Cassie-Wenzel capillarity-induced wetting transition $J$. Colloid Interface Sci. $311212-6$

[40] Godinho M, Canejo J, Feio G and Terentjev E 2010 Self-winding of helices in plant tendrils and cellulose liquid crystal fibers Soft Matter 6 5965-70

[41] Wang X, Ding B, Yu J and Yang J 2011 Large-scale fabrication of two-dimensional spider-web-like gelatin nano-nets via electro-netting Colloids Surf. B 86 345-52

[42] Zhao Y, Cao X and Jiang L 2007 Bio-mimic multichannel microtubes by a facile method J. Am. Chem. Soc. 129 764-5

[43] Yan G, Yu J, Qiu Y, Yi X, Lu J, Zhou X and Bai X 2011 Self-assembly of electrospun polymer nanofibers: a general phenomenon generating honeycomb-patterned nanofibrous structures Langmuir 27 4285-9

[44] Ahirwal D, Hébraud A, Kádár R, Wilhelm M and Schlatter G 2013 From self-assembly of electrospun nanofibers to 3D cm thick hierarchical foams Soft Matter 9 3164-72

[45] Yao T, Chen H, Samal P, Giselbrecht S, Baker M B and Moroni L 2019 Self-assembly of electrospun nanofibers into gradient honeycomb structures Mater. Des. 168107614
[46] Fukuhira Y, Kitazono E, Hayashi T, Kaneko H, Tanaka M, Shimomura M and Sumi Y 2006 Biodegradable honeycomb-patterned film composed of poly (lactic acid) and dioleoylphosphatidylethanolamine Biomaterials 27 1797-802

[47] Sunami H, Ito E, Tanaka M, Yamamoto S and Shimomura M 2006 Effect of honeycomb film on protein adsorption, cell adhesion and proliferation Colloids Surf. A 284 548-51

[48] Zhang Q, Yang X, Li P, Huang G, Feng S, Shen C, Han B, Zhang X, Jin F and Xu F 2015 Bioinspired engineering of honeycomb structure-Using nature to inspire human innovation Prog. Mater. Sci. 74 332-400

[49] Itoh H, Aso Y, Furuse M, Noishiki Y and Miyata T 2001 A honeycomb collagen carrier for cell culture as a tissue engineering scaffold Artif. Organs 25 213-7

[50] Kakudo N, Shimotsuma A, Miyake S, Kushida S and Kusumoto K 2008 Bone tissue engineering using human adipose derived stem cells and honeycomb collagen scaffold J. Biomed. Mater. Res. A 84 191-7

[51] Sato M, Asazuma T, Ishihara M, Kikuchi T, Masuoka K, Ichimura S, Kikuchi M, Kurita A and Fujikawa K 2003 An atelocollagen honeycomb shaped scaffold with a membrane seal (ACHMS scaffold) for the culture of annulus fibrosus cells from an intervertebral disc J. Biomed. Mater. Res. A 64 248-56

[52] Demir R, Seval Y and Huppertz B 2007 Vasculogenesis and angiogenesis in the early human placenta Acta Histochem. 109 257-65

[53] Adams R H and Alitalo K 2007 Molecular regulation of angiogenesis and lymphangiogenesis Nat. Rev. Mol. Cell Biol. 8464

[54] Nagata D, Mogi M and Walsh K 2003 AMP-activated protein kinase (AMPK) signaling in endothelial cells is essential for angiogenesis in response to hypoxic stress J. Biol. Chem. 278 31000-6

[55] Park H-J, Zhang Y, Georgescu S P, Johnson K L, Kong D and Galper J B 2006 Human umbilical vein endothelial cells and human dermal microvascular endothelial cells offer new insights into the relationship between lipid metabolism and angiogenesis Stem Cell Rev. 2 93-101

[56] Yang W J, Yang D D, Na S, Sandusky G E, Zhang Q and Zhao G 2005 Dicer is required for embryonic angiogenesis during mouse development J. Biol. Chem. 280 9330-5

[57] Dike L E, Chen C S, Mrksich M, Tien J, Whitesides G M and Ingber D E 1999 Geometric control of switching between growth, apoptosis, and differentiation during angiogenesis using micropatterned substrates In Vitro Cell. Dev. Biol. Animal 35 441-8

[58] Chen H, Huang X, Zhang M, Damanik F, Baker M B, Leferink A, Yuan H, Truckenmüller R, van Blitterswijk C and Moroni L 2017 Tailoring surface nanoroughness of electrospun scaffolds for skeletal tissue engineering Acta Biomater. 59 82-93

[59] Fonck E, Feigl G G, Fasel J, Sage D, Unser M, Rufenacht D A and Stergiopulos N 2009 Effect of aging on elastin functionality in human cerebral arteries Stroke 40 2552-6

[60] Si Y, Yu J, Tang X, Ge J and Ding B 2014 Ultralight nanofibre-assembled cellular aerogels with superelasticity and multifunctionality Nat. Commun. 5 1-9

[61] Li Y, Zhao R, Li X, Wang C, Bao H, Wang S, Fang J, Huang J and Wang C 2019 Blood-compatible polyaniline coated electrospun polyurethane fiber scaffolds for enhanced adhesion and proliferation of human umbilical vein endothelial cells Fibers Polym. 20 250-60

[62] Sun X, Lang Q, Zhang H, Cheng L, Zhang Y, Pan G, Zhao X, Yang H, Zhang Y and Santos H A 2017 Electrospun photocrosslinkable hydrogel fibrous scaffolds for rapid in vivo vascularized skin flap regeneration Adv. Funct. Mater. 271604617

[63] Zhao Q, Wang J, Cui H, Chen H, Wang Y and Du X 2018 Programmed shape morphing scaffolds enabling facile 3D endothelialization Adv. Funct. Mater. 281801027 
[64] Zhao Q, Cui H, Wang J, Chen H, Wang Y, Zhang L, Du X and Wang M 2018 Regulation effects of biomimetic hybrid scaffolds on vascular endothelium remodeling ACS Appl. Mater. Interfaces 10 23583-94

[65] Zhao X, Sun X, Yildirimer L, Lang Q, Lin Z Y W, Zheng R, Zhang Y, Cui W, Annabi N and Khademhosseini A 2017 Cell infiltrative hydrogel fibrous scaffolds for accelerated wound healing Acta Biomater. 49 66-77

[66] Ahmed M, Ramos T, Wieringa P, van Blitterswijk C, de Boer J and Moroni L 2018 Geometric constraints of endothelial cell migration on electrospun fibres Sci. Rep. 86386

[67] Heath D E, Lannutti J J and Cooper S L 2010 Electrospun scaffold topography affects endothelial cell proliferation, metabolic activity, and morphology J. Biomed. Mater. Res. A 94 1195-204

[68] Sundararaghavan H G, Saunders R L, Hammer D A and Burdick J A 2013 Fiber alignment directs cell motility over chemotactic gradients Biotechnol. Bioeng. 110 1249-54

[69] Giannotta M, Trani M and Dejana E 2013 VE-cadherin and endothelial adherens junctions: active guardians of vascular integrity Dev. Cell 26 441-54

[70] Simon A M and McWhorter A R 2002 Vascular abnormalities in mice lacking the endothelial gap junction proteins connexin37 and connexin40 Dev. Biol. 251 206-20

[71] Greiner A M, Sales A, Chen H, Biela S A, Kaufmann D and Kemkemer R 2016 Nano-and microstructured materials for in vitro studies of the physiology of vascular cells Beilstein J. Nanotechnol. 7 1620-41

[72] Lin Y, Shao Y, Li J, Zhang W, Zheng K, Zheng X, Huang X, Liao Z, Xie Y and He J 2018 The hierarchical micro-/nanotextured topographies promote the proliferation and angiogenesis-related genes expression in human umbilical vein endothelial cells by initiation of Hedgehog-Gli1 signaling Artif. Cells Nanomed. Biotechnol. 46 S1141-51
[73] Li M, Guo Y, Wei Y, MacDiarmid A G and Lelkes P I 2006 Electrospinning polyaniline-contained gelatin nanofibers for tissue engineering applications Biomaterials 27 2705-15

[74] Melchiorri A J, Nguyen B-N B and Fisher J P 2014 Mesenchymal stem cells: roles and relationships in vascularization Tissue Eng. B 20 218-28

[75] Fu W-L, Xiang Z, Huang F-G, Gu Z-P, Yu -X-X, Cen S-Q, Zhong G, Duan X and Liu M 2015 Coculture of peripheral blood-derived mesenchymal stem cells and endothelial progenitor cells on strontium-doped calcium polyphosphate scaffolds to generate vascularized engineered bone Tissue Eng. A 21 948-59

[76] Zacharek A, Chen J, Li A, Cui X, Li Y, Roberts C, Feng Y, Gao Q and Chopp M 2007 Angiopoietin1/Tie2 and VEGF/Flk1 induced by MSC treatment amplifies angiogenesis and vascular stabilization after stroke J. Cereb. Blood Flow Metab. 27 1684-91

[77] Wang M, Crisostomo P R, Herring C, Meldrum K K and Meldrum D R 2006 Human progenitor cells from bone marrow or adipose tissue produce VEGF, HGF, and IGF-I in response to TNF by a p38 MAPK-dependent mechanism Am. J. Physiol. Regul. Integr. Comp. Physiol. 291 R880-4

[78] Liang T, Zhu L, Gao W, Gong M, Ren J, Yao H, Wang K and Shi D 2017 Coculture of endothelial progenitor cells and mesenchymal stem cells enhanced their proliferation and angiogenesis through PDGF and Notch signaling FEBS Open Bio 7 1722-36

[79] Ball S G, Shuttleworth A C and Kielty C M 2004 Direct cell contact influences bone marrow mesenchymal stem cell fate Int. J. Biochem. Cell Biol. 36 714-27

[80] Rouwkema J, Boer J D and Blitterswijk C A V 2006 Endothelial cells assemble into a 3-dimensional prevascular network in a bone tissue engineering construct Tissue Eng. 12 2685-93 